\title{
An Assessment of Construction Workers Health Profile and Body Pain
}

Tariq Umar MSc, CEng IntPE (UK), MICE

PhD Candidate London South Bank University, UK/ Lecturer, College of Engineering, A'Sharqiyah University, Oman.

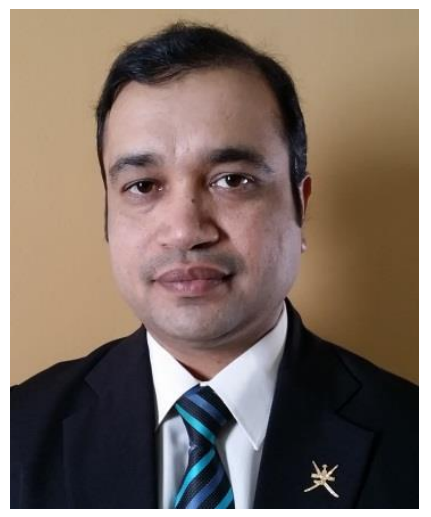

Charles Egbu PhD, FRICS, FCIOB, FAPM, FRSA, FHEA

Dean of School of the Built Environment and Architecture, London South Bank University, UK.

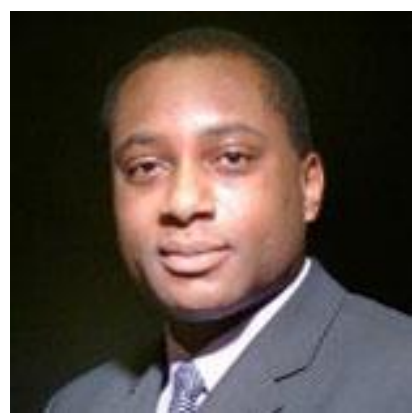

Mohamed Shaik Honnurvali M-Tech, MIET

PhD Candidate Edinburgh Napier University, UK/ Lecturer, College of Engineering, A'Sharqiyah University, Oman.

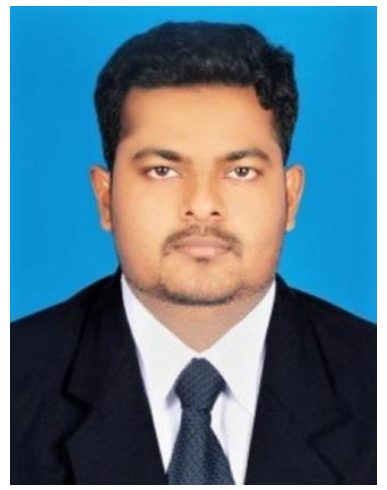


Messaoud Saidani

BEng, PhD, PgCertLT, CEng, MIStructE

Head of Research, School of Energy, Construction and Environment

Faculty of Engineering, Environment and Computing,

Coventry University, UK.

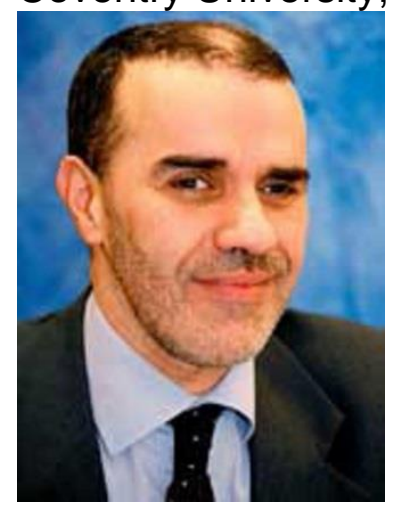

Matira Al-Mutairi, PhD

Associate Professor, Department of Geography Climatic and environmental geography, Princess Nora bint Abdulrahman University, Saudi Arabia.

\section{Abstract:}

Construction is one of the most hazardous and complex industries worldwide which result into the most fatal accidents and occupational illnesses. It is also regarded as a major industry in not only in Gulf Cooperation Council (GCC) countries but worldwide and it is rapidly growing. This study reports an assessment of different body parameter including physiologic factor, and body pain of construction workers from GCC countries. Demographic Data was collected through face to face interview followed by the measurement of BMI, blood pressure and heartbeat. Data for musculoskeletal pain was collected through a structured questionnaire. The results reveal that a majority of workers were overweight or obese. The blood pressure of $43.3 \%$ of the participant was more than the threshold and fall under the hypertension values. $46.6 \%$ of the workers informed to have experienced body pain in the last three months, while the most frequent reported areas for pain were neck, shoulder, lower back, leg and Knees. Sleeping hours was one of the factors which are considered to be affecting on pain experience of workers. The finding of this research would be helpful to develop strategies to improve the well-being of construction workers in GCC countries.

Keywords: Health \& safety, Safety \& hazards, Management.

\section{Introduction:}


International Labor Organization data for the year 2015 indicate that every year 108,000 workers died on construction site due to different occupational safety and health condition. This number is nearly $30 \%$ of all occupational deadly injuries. Different statistic reveals that construction workers in different developed countries are 3 4 times more likely to die from accidents at site compared to workers in other industries. In the developing world, There is a higher risks (3 6 times more) of death linked with construction work in developing countries (ILO, 2015). Many construction workers suffer and die from work related diseases developed from past influence to risky materials, such as asbestos and other chemicals. Umar (2016-a), while comparing the cost of accidents in construction industry of UK and USA; concluded that such cost could be $7.5 \%$ of the tender value of a construction project. Construction industry is known as one of the world's major industrial sectors, which include sub-sectors such as building, civil engineering, demolition and maintenance. It accounts for a considerable proportion of GDP in different countries for instance, $6.10 \%$ in the U.K., $5.50 \%$ in Japan, and $9.0 \%$ in Oman (ONS, 2017; SHJ, 2017; NCSI, 2017). Construction industry is rapidly growing in different developing countries and thus recognized as a main sources for providing jobs to different labors. It is expected that spending in construction sector will rose up to 14 Trillion (US \$) in 2025, which was only 9.5 Trillion (US \$) in 2014 (figure 1), representing a growth of $47 \%$ (Statista, 2017). Although, In GCC countries, the economy is heavily reliant on oil and grad export and contributes up to $80 \%$ of the total earning (Umar and Wamuziri, 2016-a; Umar, 2017-a; Umar, 2017-b; Umar and Egbu, 2018-a). In recent years, the dip in oil and gas prices somehow affected the GCC construction industry as well (Umar and Egbu, 2018-b). A comparison of the contract awarded in the GCC countries, in the first quarter of 2017 and 2018 shows an overall decline of US $\$ 5.0$ Billion (Ventures, 2018-a). The construction contract awarded in the first three months of 2017 and 2018, in GCC countries are shown in figure 2. In Saudi Arabia, the awarded construction contracts in 2018 related to building, infrastructure and energy are US \$ 5917 Billion more from the similar contract awarded in 2017 as presented in figure 3 (Ventures, 2018-b). While there is an impact on construction industry due to economic situation, however different studies shows that construction will be growing in near future (Umar et al., 2018). At the same time construction industry is recognized as one of the risky industries. The construction workers job may include variety of task while they are working in different projects. These projects may be related to building, repair and maintenance; renovation and demolishing; transportation including construction of highways, bridges and airports; and projects related to docks and harbors. Construction workers are expected to be open to different types of risk during their works such as dust and condensation; stiff working situation; handling heavy load; hot climatic condition; working at heights; excessive noise; vibration and heavy machinery; and different chemicals. Different causes of accidents and illness in construction industry are renowned and thus can be prevented (ILO, 2015). Many 
researchers proposed a variety of ways to improve of construction safety for the benefits of both the workers and organizations. Umar (2016-b) stressed on the universal definition of the safety leadership as he considered that in absence of a clear definition of safety leadership may result into the confusion in safety expectations and will disturb the safety efforts. Similarly, Umar and Wamuziri (2016-b) while exploring the challenges and opportunities for improvement of occupational safety and health in Oman, concluded that there is a need for establishing of an independent organizations responsible for the implementation of occupational safety and health regulations in Oman. Another aspect of the safety improvement is to know that root causes of accidents so that strategies can be developed to avoid such causes in the future projects (Umar et al, 2017; Umar and Egbu, 2018-c).

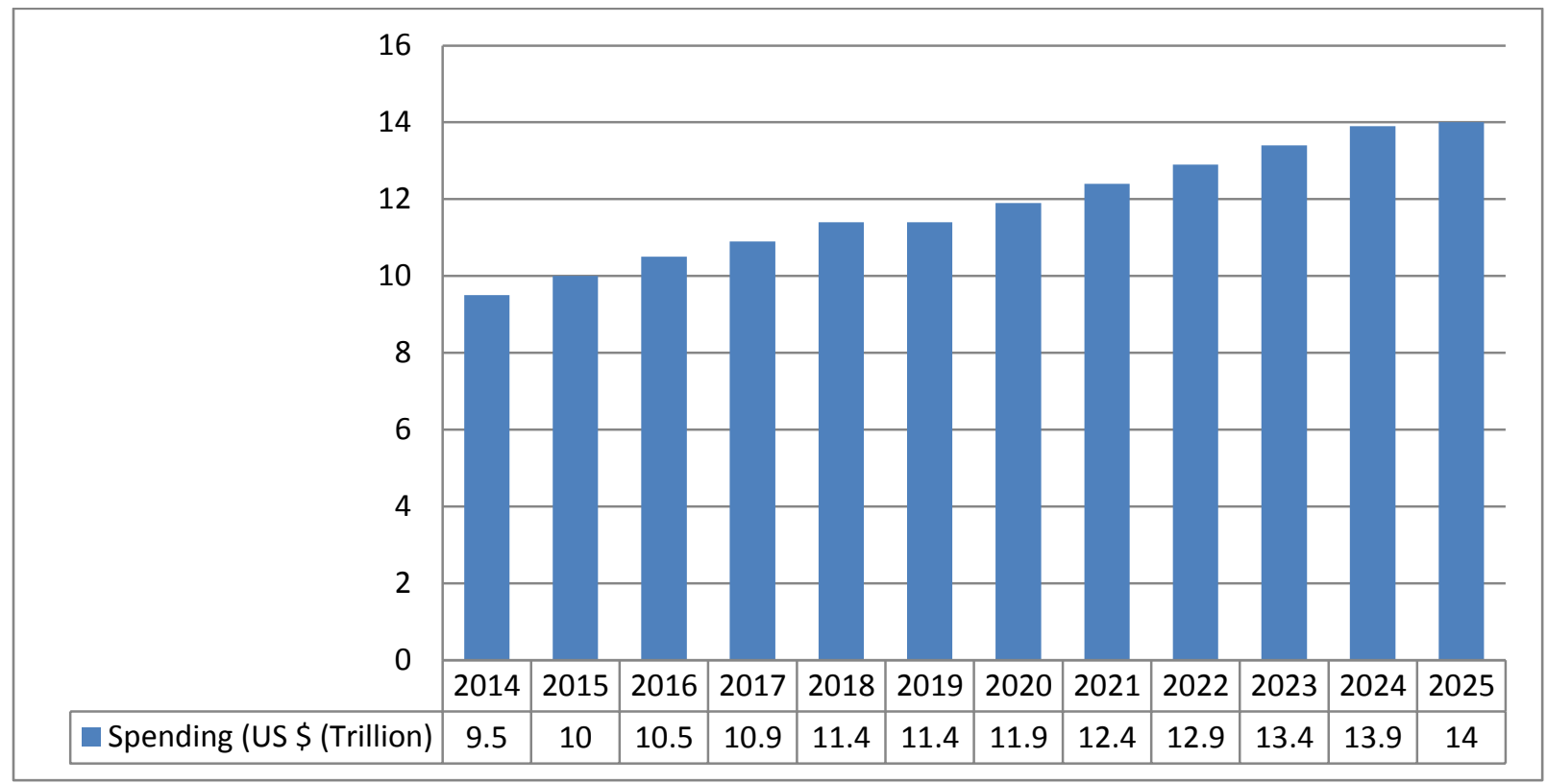

Figure 1: Global Construction Industry Growth (Statista, 2017). 


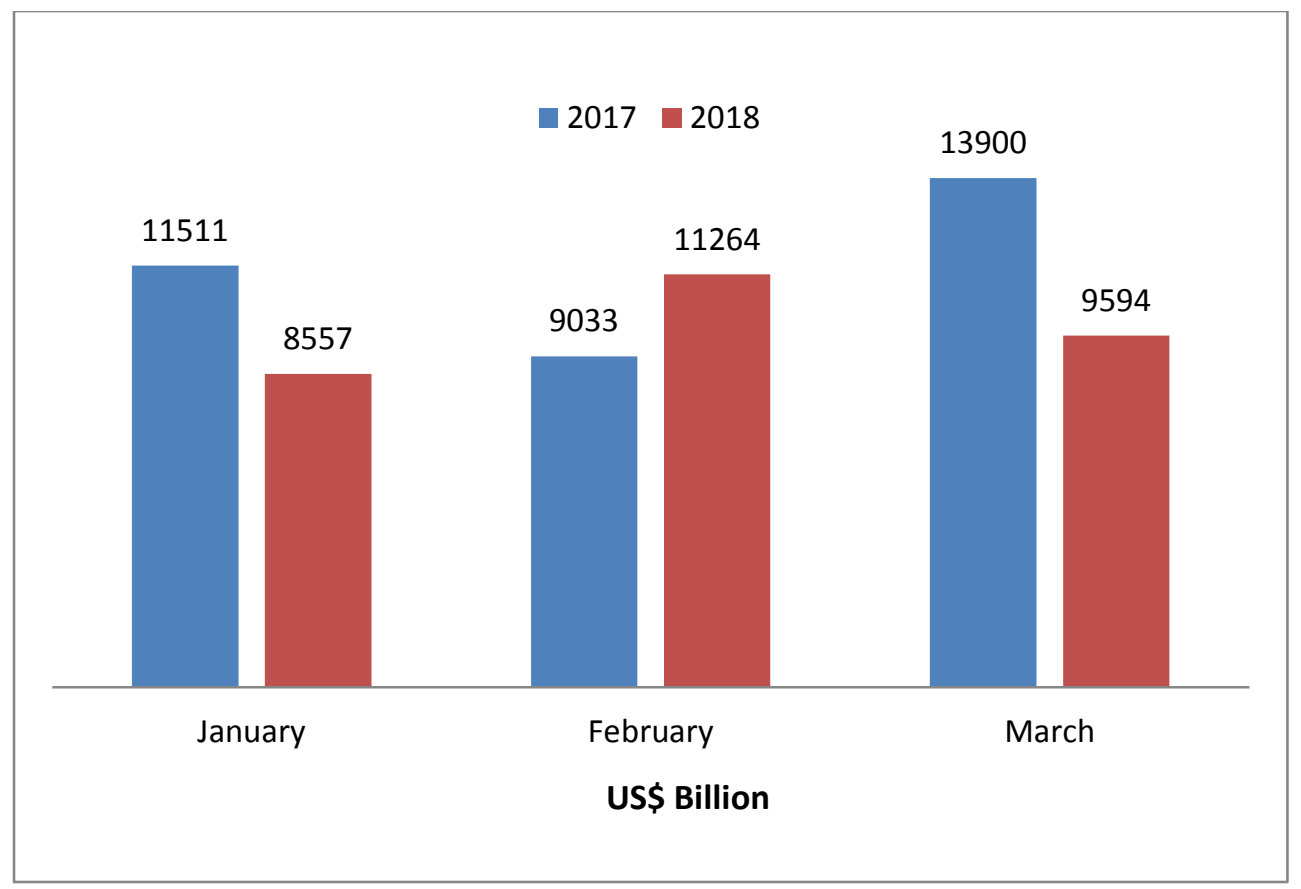

Figure 2: Comparison of Awarded Construction Contracts In GCC (Ventures, 2018-a).

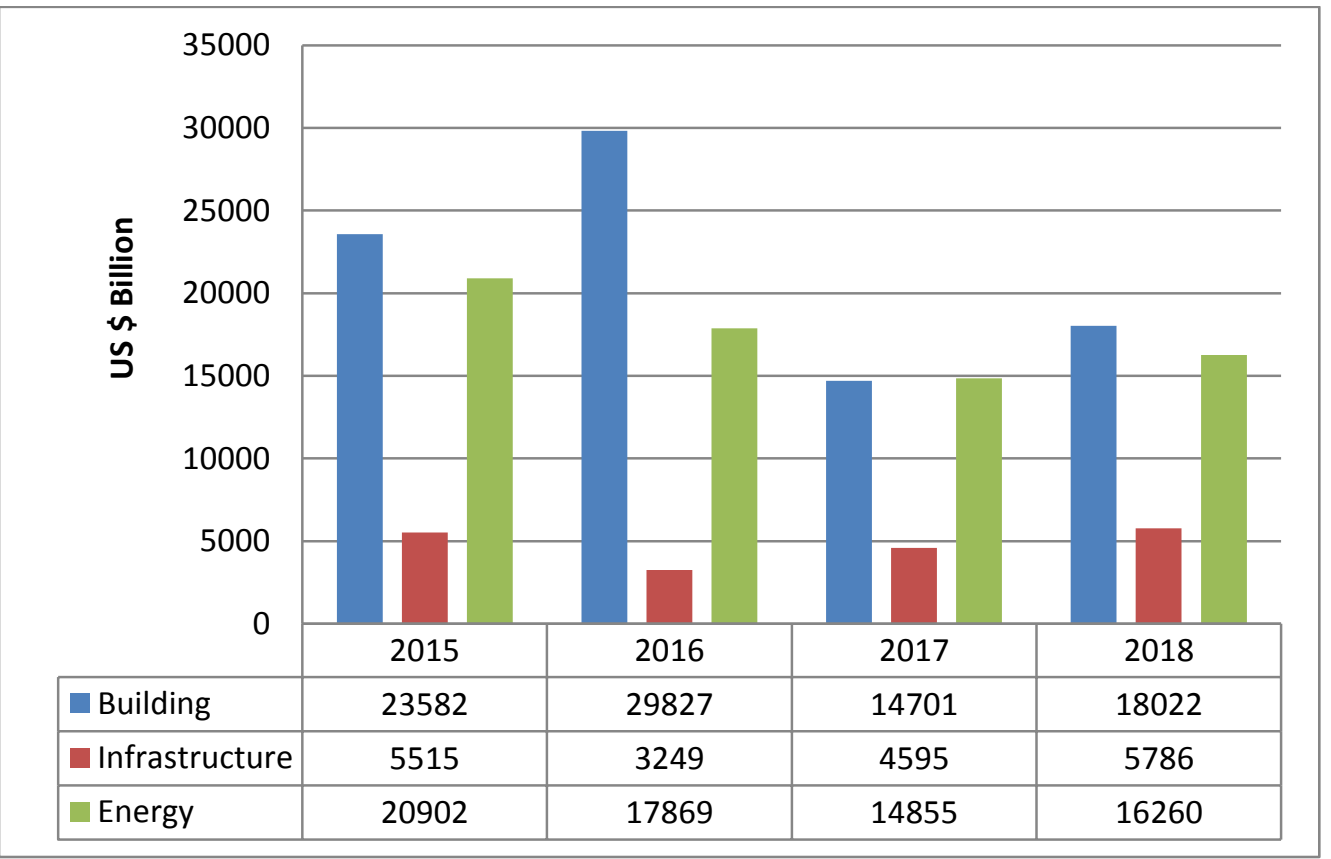

Figure 3: A Comparison of Awarded Contracts in Saudi Arabia (Ventures, 2018-b).

In GCC countries, majority of the construction workers are foreigner. For instance, in Saudi Arabia construction industry expatriate workers account for $80 \%$ of whole industry (SCA, 2017). Similarly, in Oman $92 \%$ of construction workers are foreigner (NCSI, 
2015). Construction sector in the United Arab Emirates (UAE), employed the highest number of people $(1607,000)$ where majority of them are expatriates (Statista, 2016).These statistics are based on the overall number of workforce in this industry which represents all population in the industry including managers, engineers and labours. In reality, the labours in these countries are all totally foregoer, coming from south Asian and African countries. Construction remains as the most of the top industry which employ a high number of foreigner workers. Statistics indicates that in Qatar most of the foreigner workers are employed by construction section where the number of workers rose approximately $700 \%$ from 2006 to 2015 as shown in figure 4 (GLMN, 2017). These foreigner workers normally reside in companies' accommodation. As such these foreigner workers are not medically insured under the government organization scheme. The insurance law however, bound construction organizations to have medical and life insurance for their workers. Since the risk liked with construction industry is high, therefore the insurance cost for construction workers is relatively high as well. It is expected that construction organizations will have to carry high cost at the time of hiring and pay for repatriation, compensation and replacement in case of accidents involved injuries and death. For instance, Umar et al (2018), while reviewing the Occupational Health and Safety (OS\&H) regulations in Oman, quoted the data of Public Authority of Social Insurance in Oman and concluded that the expenditures related to OS\&H rose from 1 Million OMR ( $=2.6$ Million US\$) in 2012 to 2.9 Million OMR (=7.53 Million US\$) (figure 5). Although the number of active insurees also increased in this period from 172066 in 2012 to 227193 in 2016 which represent a growth of 32\% (figure 6); however the increase in OS\&H expenditures in the same period was $200 \%$. Several studies have concluded that physical health factors such as elevated blood pressure, weight and sleeping habit of workers has a direct impact on safety outcomes (Beevers and MacGregor, 1999; Rees et al, (2013); Dua et al (2014); Yi and Chan, 2016). This article presents the research conducted on construction workers health profile and body pain. The purpose of this research was to determine the construction workers' health profile including Body Mass Index (BMI), blood pressure, heart rate and to assess their musculoskeletal pain considering pain experience, pain treatment, and its impacts on daily routine life. 


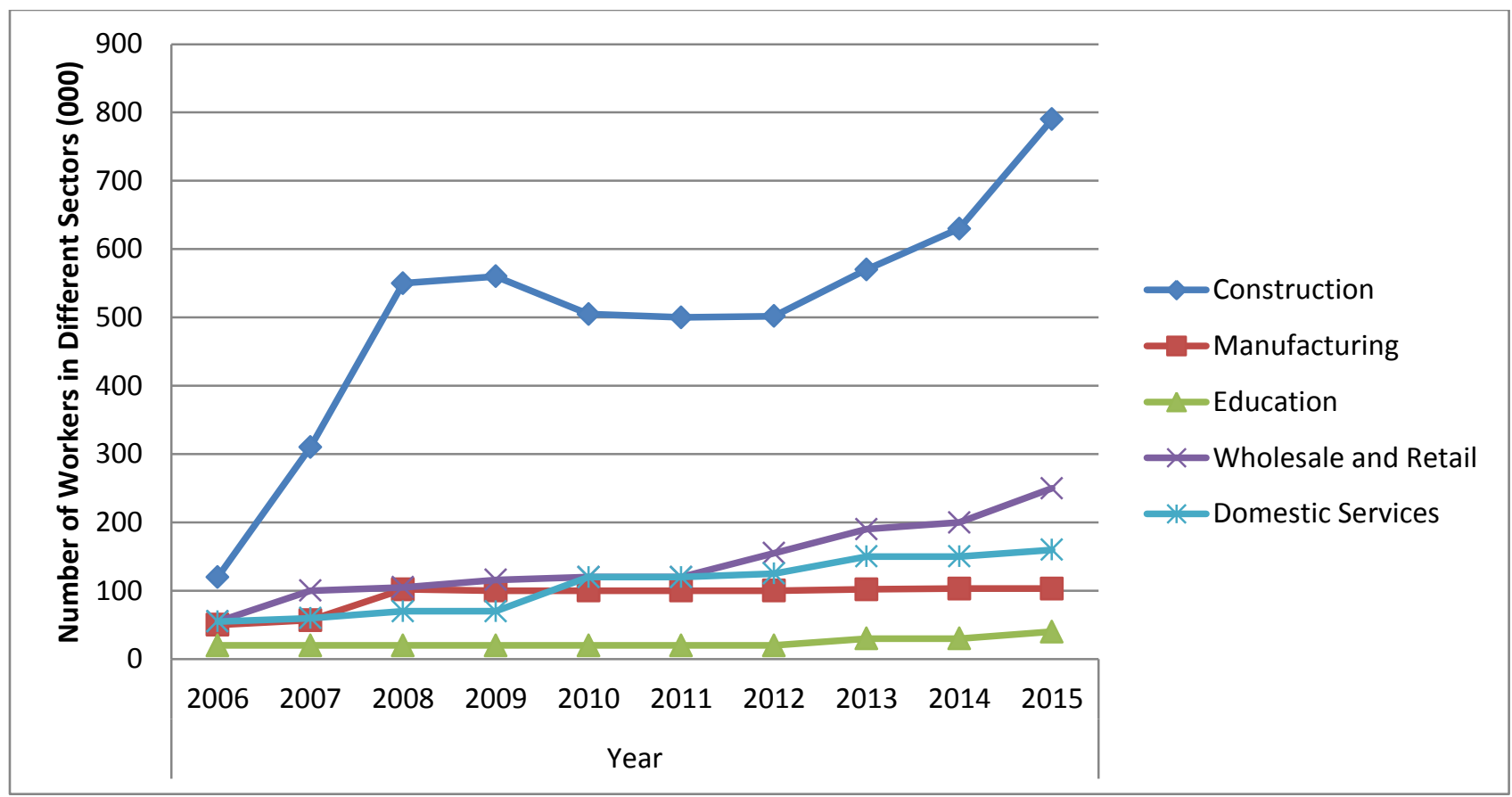

Figure 4: Projection of Construction Workers in Qatar (GLMN, 2017).

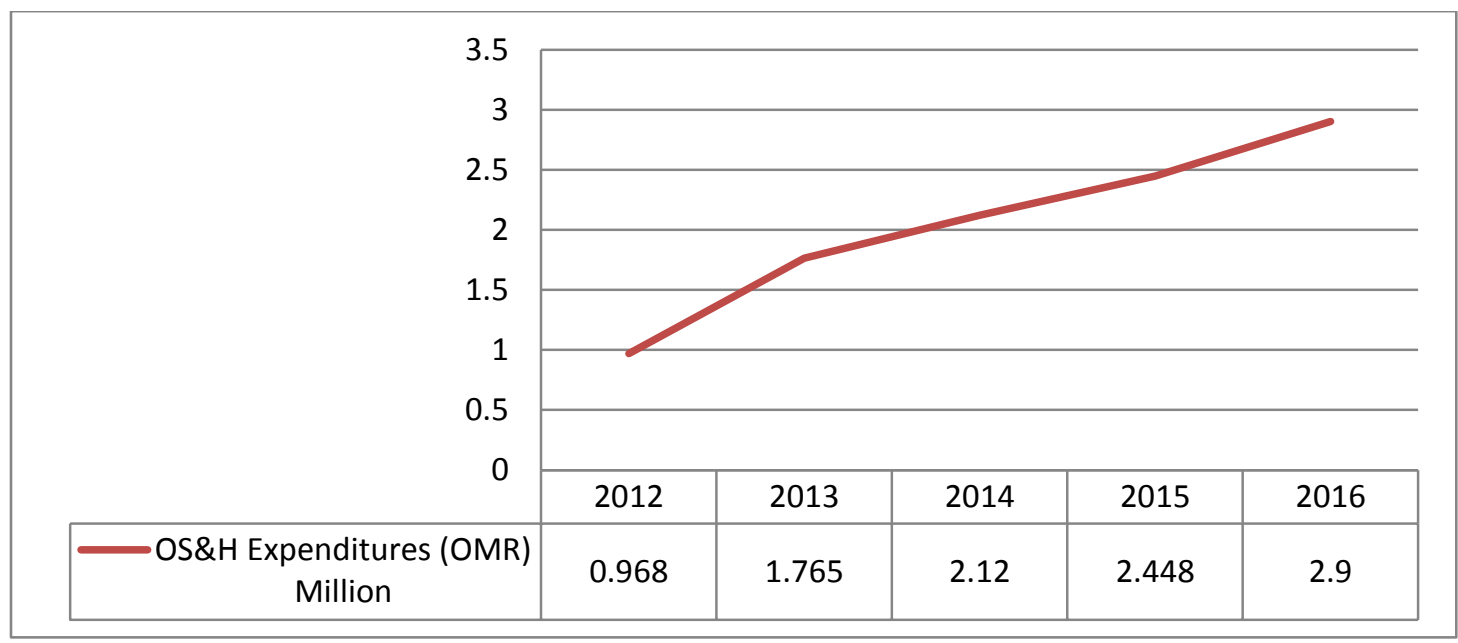

Figure 5: An Increase in OS\&H Expenditure (PASI, 2012, PASI, 2013, PASI, 2014, PASI, 2015, PASI, 2016). 


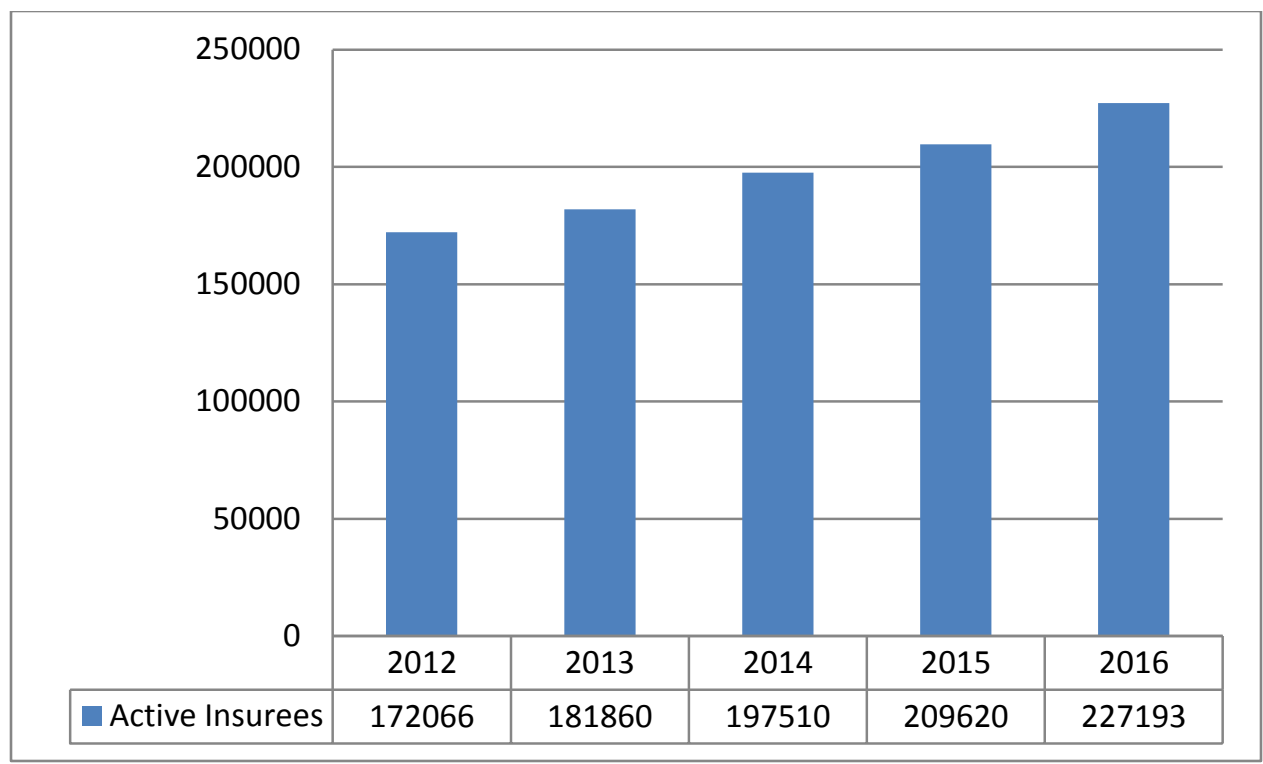

Figure 6: Number of Registered Insurees in PASI ((PASI, 2012, PASI, 2013, PASI, 2014, PASI, 2015, PASI, 2016).

\section{Workers' Health Profile and Body Pain:}

Delay in construction project is a usual phenomenon around the world which occurs due to several internal and external factors which includes poor definition and tracking, technical barriers, inadequate resources, changing priorities, wrong project, weather, competitors and legal barriers (Nicholas and Steyn, 2017). Assaf and Al-Hejji (2006) observed that $30 \%$ of the construction project in Saudi Arabia complete on time while remaining $70 \%$ delays. Similarly, the National Audit Office report in the UK, quoting the data before the year 2000 , shows that $70 \%$ of the government construction project delay (NAO, 2003). Workforce related factors such as labor productivity, labor skills and labor availability are regarded some of the key delaying factors by many researchers (Kaming et al., 1997; Chan and Kumaraswamy, 1997; Assaf and Al-Hejji, 2006; Sambasivan and Soon, 2007; Umar, 2018).

Many researchers have linked the productivity and safety performance of construction workers with their physical health (Yi and Chan, 2016; Yi and Chan, 2017; Umar and Egbu, 2018-a; Umar and Egbu, 2018-b). There have been several research studies on physical examination which were carried out among different occupations and industries. Body Mass Index (BMI) and body blood pressure were some of the common factors which were considered in these studies. For instance, BMI was considered in a research study conducted by Kawai et al. (1995) to assess health profile of 816 white collar workers in Japan. Umar and Egbu (2018-d) while discussing the heat stress as a 
main cause of accidents in construction, observed that based on the BMI results $80 \%$ of the participants in their selected sample were overweight or obese. According to Dua et al. (2014), an increased BMI being linked with prehypertension may advise that such persons are at high risk of progressing to frank hypertension. A research conducted in Denmark by Gupta et al. (2018) reported the BMI of 147 blue collar workers from a variety of professions including construction and observed that $\mathrm{BMI}$ of $59 \%$ of the participants was more than 25. The mean value of the BMI of the selected participants was 26.4 \pm 4.80 . Similarly, the mean BMI of 932 construction workers in Hong Kong reported by $\mathrm{Yi}$ and Chan (2016) was $24.3 \pm 3.70$. Their reported BMI results further reveal that $2.8 \%$ of the participants were underweight, $36.1 \%$ were overweight and $6.5 \%$ were obese. The finding of a similar research conducted on 314 male construction workers in Netherland shows that based on the BMI results, $70 \%$ of the participants were classified as overweight and $22.7 \%$ as obese. (Viester et al., 2017). The BMI result from different studies, however, clearly reflects that the majority of construction workers are not in their healthy range of BMI, which will have different consequences". Similarly, musculoskeletal pain is common in construction workers worldwide (Goldsheyder et al., (2004); Boschman et al., 2012). This is because of construction workers required to perform physical demanding tasks repeatedly with awkward position and more force. Construction workers body pain is considered as one of the most important cause of accidents at construction sites (Yi and Chan, 2016). 77\% of the total construction workers around the world are recognized to have the musculoskeletal pain or disorder (Punnett and Wegman, 2004). For instance, in Taiwan, 76.2\% of the construction reported the body pain and the most frequent reported areas for such pain were the shoulder, neck, and low back (Leung et al, 2012). The results of the a survey from US construction industry reveals that approximately $77 \%$ of the workers suffer from musculoskeletal pain, while the lower back area was the most frequent reported for such pain (Goldsheyder et al., (2004). A study conducted by Hanklang et al (2014) on musculoskeletal disorders and pains among Thailand female construction workers, reported that around $58 \%$ of these female workers experience body pain while the mostly reported area for such pain remained lower back and shoulders. Musculoskeletal disorders and pains are further considered as a major cause for disability, absenteeism and reduced workability. For instance, in Canada, the injuries caused by musculoskeletal pain or disorder result up to $47 \%$ of the total injuries claims and around $42 \%$ of the lost time claims (ACSA, 2008). Although construction is a major industry in Oman and other GCC countries, however less attention is given to this topic as part of the workers wellbeing. In reality, a better understanding of workers' body pain will help construction organizations to make strategies to improve the work and health related elements which can be helpful in managing such pain. Such efforts will benefits both the workers and organizations. The absence of workers body pain will increase their wellbeing and the organizations will be benefit through an improved productivity. 


\section{Research Methodology:}

Data used in this research was collected from a variety of volunteers' construction workers working in Oman. The sample of 30 construction workers was selected in a way to avoid the language barrier, thus the workers who were able to communication in local languages such as Urdu, Punjabi, Hindi and Pushto were selected. The selected workers were briefed about the purpose of the interview to reduce any pressure they may have and to allow them to share the accurate information. The physical test and face to face interview was conducted during lunch break at construction site which took approximately 20 minutes per participant. Prior to data collection, authors took appropriate training to measures blood pressure and resting heat beat correctly. All anecdotal data was collected in the presence of a medical practitioner to avoid any error.

Workers individual characteristics and work associated factors such as age; sleeping habit, nationality, and working experience in construction industry were obtained in a semi-structured interviews. The weight and height of each participant was measured for the purpose of calculation of BMI. A BMI measurement is used to determine if an adult is at a healthy weight for their height. An individual's is determined by dividing their weight in $\mathrm{Kg}$ by the square of their height in $\mathrm{m}^{2}$ (Equation No.1). The BMl values from 18.5 to 25 are considered as normal (WHO, 2017). For example, an adult who is $17.5 \mathrm{~m}$ tall and weighs $70 \mathrm{~kg}$ will have a BMI of 22.9 , which is in the normal healthy range.

$B M I=\frac{W}{H^{2}}$ Equation No.1 (WHO, 2017)

Where,

$B M I=$ Body Mass Index

$W=$ Weigh in $\mathrm{Kg}$

$H=$ Height in meter

The smoking habits of the participants were measured as "none", if the worker was smoking no more than 35 cigarettes per week, and as "yes", if the worker was taking more than 35 cigarettes per week. Participants were classified as occasional smoker if they were not a regular smoker and smoking was done occasionally. Systolic Blood Pressure (SBP) Diastolic Blood Pressure (DBP) and heat rate (HR) at resting of the participants were measured with sphygmomanometer and pulse oximeter. The average of two reading were considered and reported in this article.

For evaluation of Musculoskeletal Pain of workers, a pain experience questionnaire consist of nine items was used to assess workers' recognized pain problems. Such 
questionnaire which measures the recognized pain was witnessed to be a simplest and accurate approach for pain estimation by many researchers (Tse et al., 2010; Tse et al., 2013; Yi and Chan, 2016). Item No. A of the questionnaire was including the optional information such as name and organization of the respondents. In item No. B of the questionnaire, the discomfort and pain including muscular, connecting tissue, collagen, and joint discomfort or pain caused by work in the past three months was enquire from participants. The responses of participants were recorded on the questionnaire as "yes" or "no". The workers were also asked to indicate the location of discomfort or pain in figure 7 (item $C$ ). In items $D, E$ and $F$ of the questionnaire, the workers were asked to rate the severity of pain symptoms on a scale of 1 to $10(1=$ very mild pain, $10=$ unbearable pain) for the pain they experienced over the past 24 hours and the pain they felt now (items D, E and F). To know the types of the treatment the workers are using for the relief of discomfort and pain, the participants were asked if they had ever used any pain treatment. Responses for the types of treatment were categorized in item $G$ of the questionnaire as follows: ignore the pain, use of pain killers, use of medical cream, carried out massage, use of health product, use of physical therapy, doing exercise, or others treatment. Under item I of the questionnaire, the response on the relief after treatment was sorted out on a scale of 0 to $10(0=$ no remission, $10=$ complete remission). In the last item of the questionnaire, the workers were inquired to rate if their pain have disturbed their daily life by changing their mood, affecting walking and work ability, affected their relationships with friends or family, affected their sleeping habit or hobbies. Thus item No. I, included six sub-items. The response of the participant was recorded on a scale of 1 to 5 . ( $1=$ strongly disagree, $5=$ strongly agree). 

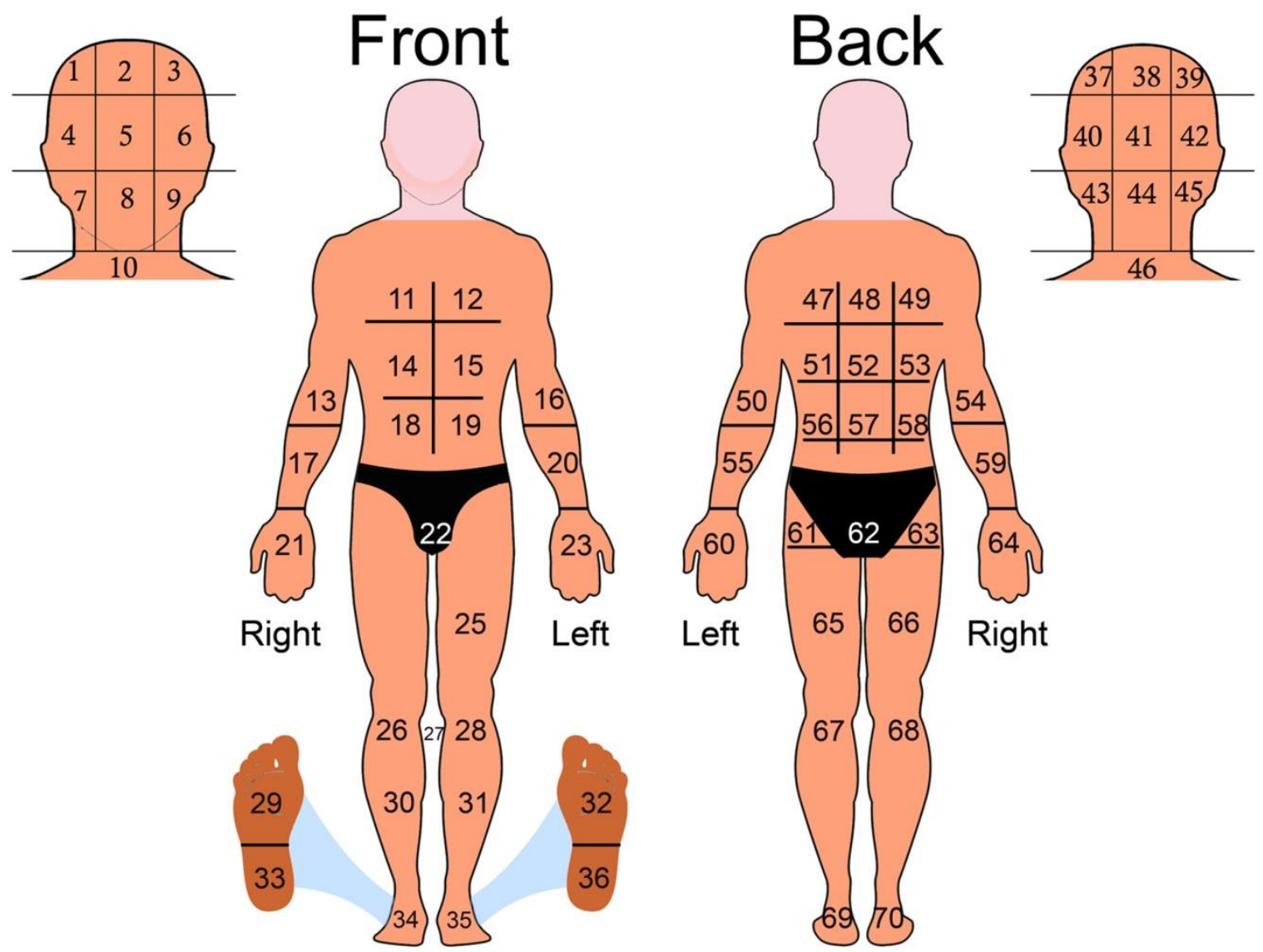

Figure 7: Body areas for Pain Assessment

Statistical analyses were performed using computer software program SPSS 23.0. For statistical analysis, descriptive statistics approach which included averages and ratios on different factors were used. To know the significance of sleeping habit on workers' health, T-test was performed. In this analysis, two sets of sleeping habit (daily sleeping hours less than seven and equal to seven) was used in relation to musculoskeletal pain. One-way analysis of variance (ANOVA) was run on the average of the workers' health factors such as age, BMl and smoking habit to establish if there are any important differences between the means of groups. Further analyses were conducted on workers who have physical results exceeding the safety verge. The impacts of age, BMI, ethnicity, smoking habit, and working experience on the musculoskeletal pain were determined by performing regressions analysis. 


\section{Results and Discussion:}

\subsection{Demographic Information:}

All the 30 workers participated in this study were male while majority of them were from India, follow by Pakistan, Bangladesh and then Siri Lanka as shown in table 1. The average age of the workers was 33.26 years ranging from 20 years to 51 years. The results of $\mathrm{BMI}$ indicate that there is no worker which can be classified as underweight (BMI 18.5 ). The average value of BMI was 27.32 which indicates that majority of the workers are overweight $(\mathrm{BMI} \geq 25)$. Overall, the $\mathrm{BMI}$ of eight participants $(26.7 \%)$ was in the normal range $(\mathrm{BMI}=18.5-25), 14$ participants $(46.7 \%)$ were found to be over weighted as per the result of their $\mathrm{BMI}(\mathrm{BMI}=25-30)$. The $\mathrm{BMl}$ of remaining eight participants (27\%) was greater than 30 , thus classified as obese. It is clear from the results of the BMI that majority $(73.3 \%)$ of the construction workers are overweight or obese. Research conducted by Dua et al (2014) suggest that an increased value of BMI being linked with prehypertension may advise that such individuals are at expanded exposure of progressing to direct hypertension. Although the percentage of overweight or obese $(73.3 \%)$ seems to be alarming, however it appears to be an issue in most of the construction industries globally. For instance, in Hong Kong, Netherlands and Germany the percentage of overweight and obese in construction industries are $42.6 \%$, 75\% and 63.7\% respectively (Yi and Chan, 2016; Groeneveld et al., 2008; Claessen et al., 2009). The results show that the average sleeping hours of the participants is 4.5 hours. Research conducted by Lombardi et al. (2010), on daily sleep and risk of workrelated injury interviewed 177,576 persons (ages 18-74) and estimated that annual injury rates/100 workers were 7.89 , if the daily sleeping hours remains less than 5 hours. There have been growing evidences that short sleep duration is linked with many chronic disease outcomes, such as diabetes, hypertension, cardiovascular disease, obesity and other sickness which results into absences from work (Gottlieb et al., 2005; Gangwisch et al., 2006; Ayas et al., 2003; Di Milia and Mummery, 2009; Marshall et al., 2008; Singh et al., 2005; Westerlund et al., 2008). From the smoking habit, it was found that 12 participants $(40 \%)$ have no smoking habit. 11 participants $(36.66 \%)$ were classified and occasional smokers while 7 participants (23.33\%) were daily smokers. Smoking is considered as one of the main cause for high blood pressure and hypertension, thus for Prevention and treatment for both of them, quitting smoking is normally recommended (Daskalopoulou et al., 2015). The trade classification of all the participants is shown in figure 8 . 


\begin{tabular}{|l|c|c|c|c|c|}
\hline Characteristic & Number & Min & Max & $\begin{array}{c}\text { Mean } \pm \\
\text { Standard } \\
\text { Deviation }\end{array}$ & Percentage \\
\hline Age & 30 & 20 & 51 & $33.26 \pm 8.95$ & - \\
\hline BMl & 30 & 22 & 33 & $27.32 \pm 3.17$ & - \\
\hline $\begin{array}{l}\text { Sleeping } \\
\text { Hours }\end{array}$ & 30 & 4.5 & 10.5 & $7.21 \pm 1.83$ & - \\
\hline Smoking & -- & -- & -- & -- & -- \\
\hline No Smoking & 12 & - & - & - & 40 \\
\hline $\begin{array}{l}\text { Casual } \\
\text { Smoking }\end{array}$ & 11 & & & & 36.66 \\
\hline Daily Smoking & 7 & - & - & - & 23.33 \\
\hline Ethnicity & - & - & - & - & - \\
\hline Indian & 13 & - & - & - & 43.33 \\
\hline Bangladeshi & 9 & - & - & - & 30 \\
\hline Pakistani & 7 & - & - & - & 23.33 \\
\hline Siri Lankan & 1 & - & - & - & 3.33 \\
\hline $\begin{array}{l}\text { Working } \\
\text { Experience in } \\
\text { years }\end{array}$ & 30 & 1 & 21 & $5.54 \pm 4.97$ & - \\
\hline
\end{tabular}

Table 1: Demographic Information of the Participants

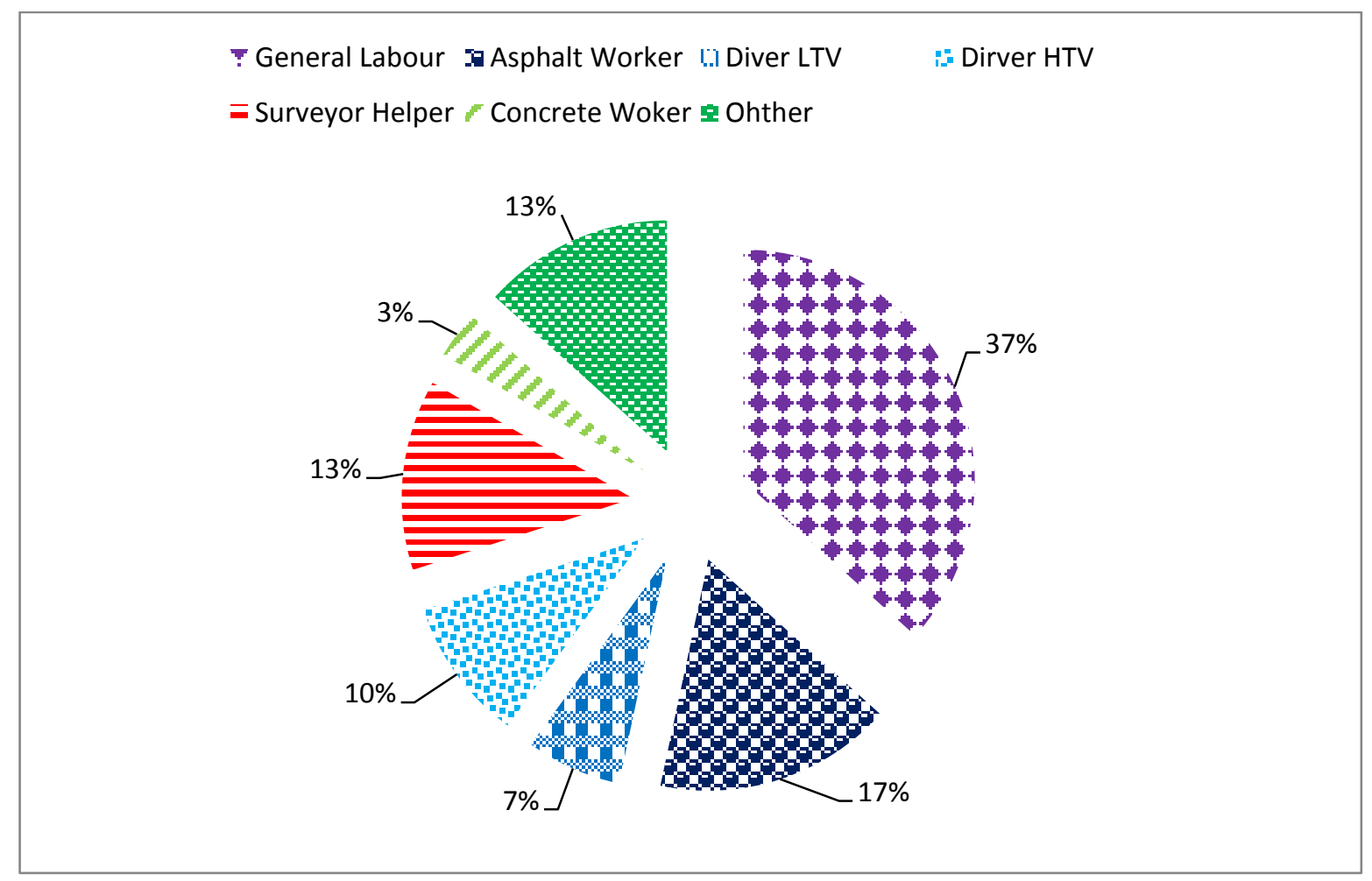

Figure 8: Trade Classification of Participated Workers 


\subsection{Blood Pressure and Heart Rate:}

Carey and Whelton (2018) noted that hypertension is the major reason of death and disability internationally. A high blood pressure is regarded as a main cause of hypertension (Daskalopoulou et al., 2015). Poulter et al., (2015) concluded that if a person is having a blood pressure more than or equal to $140 \mathrm{mmHg}$ SBP or more than or equal to $90 \mathrm{mmHg}$ DBP is to be classified a hypertension. Similarly, the American Heart Association classified the mean resting heart rate for adults is to be from 60 to 100 beats per minutes (bpm), and for well-trained athletes it is to be from 40 to $60 \mathrm{bpm}$ (AHA, 2018). The results of this study reveal the average DBP of all the participants was equal to $78.3 \pm 14.7(\mathrm{mmHg})$. Similarly, the average SBP of all the participants was calculated at $136.2 \pm 18.3(\mathrm{mmHg})$. The results further reveals that $43.3 \%$ (13 participants) blood pressure was more than the threshold and the fall under the hypertension values. The average value of RHR was found as $78.5 \mathrm{bpm}$, ranging from $56 \mathrm{bpm}$ to $113 \mathrm{bpm}$. While the RHR of some of the participants $(6.66 \%)$ were lower and for one of the participant it was higher than the normal, however it seems to be usual as indicated by the American Heart Association (AHA, 2018).

\subsection{Musculoskeletal Pain:}

The questionnaire for the assessment of musculoskeletal pain was prepared in English, however, since none of the respondents were able to complete the questionnaire, thus assistance was provided to them for translation of the questions and to record their response on the questionnaire completely. This enabled all the respondents to complete the questionnaire. A total of $14(46.60 \%)$ workers reported that they suffered from pain or discomfort in the last three months. The results indicate that most of the workers (13 out of 14) who reported to suffered from pain were 35 years or above 35 years old ( $8 \geq$ $40 ; 5 \geq 35-40$ ). The areas of the body which were frequently reported by worker for the pain is shown in table 2 and the severity of the pain is presented in table 3 . Lower back was one of the areas which were reported more frequently for the pain (39.4\%). The average of the pain of 14 workers who reported pain or discomfort on a scale of $1-10$ ( $1=$ very mild pain, $10=$ unbearable pain) was $3.68 \pm 2.14$. 


\begin{tabular}{|c|c|}
\hline Area of Pain & Reported Frequency (\%) \\
\hline Neck & 12.67 \\
\hline Shoulder & 15.30 \\
\hline Lower Back & 39.40 \\
\hline Leg & 14.52 \\
\hline Knees & 18.11 \\
\hline
\end{tabular}

Table 2: Frequent Reported Areas for Musculoskeletal Pain

\begin{tabular}{|l|l|}
\hline Severity of Pain & Mean \pm Standard Deviation (SD) \\
\hline Extreme Pain Over the Past 24 Hours & $5.4 \pm 2.4$ \\
\hline Slightest Pain Over the Past 24 Hours & $2.3 \pm 2.0$ \\
\hline Average Pain Over the Past 24 Hours & $3.9 \pm 2.1$ \\
\hline Present Pain & $2.7 \pm 2.4$ \\
\hline
\end{tabular}

Table 3: Severity of Musculoskeletal Pain

Statistical analysis shows that the sleeping habit was important in worker reported pain severity. The mean pain for workers with seven or more than seven hours daily sleep hours $(3.13 \pm 2.1)$ were less than that of those with less than 7 hours of daily sleep $(3.87 \pm 1.97)$.

\subsubsection{Treatment of Pain:}

The workers were inquired to indicate the approaches they implied to get relief from the pain. Figure 9 shows the methods reported by the workers who supper from pain. The use of pain killers (57\%) was more common treatment adopted by these workers. Three out of fourteen workers (22\%) reported that they just ignore the pain. The use of medical cream, massage and exercise was also reported by workers as a method of relief from pain. 


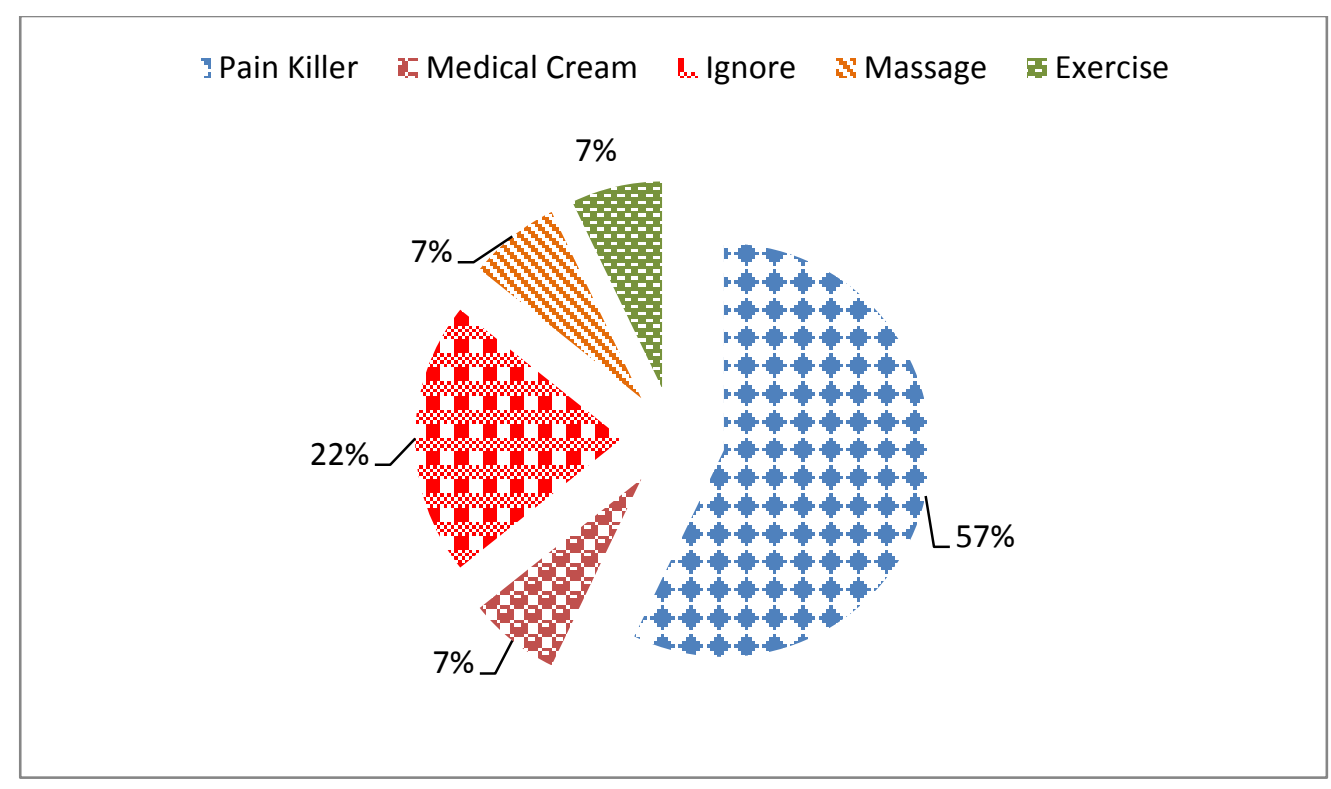

Figure 9: Pain Relieving Methods

\subsubsection{The impacts of Pain on Workers Life:}

To understand the impacts of musculoskeletal pain, workers were requested to rate the impact of pain on their daily life including mood, walking ability, work, relationships, sleep, and hobbies, on a five point Likert scale ranging from $1-5$ (1= strongly disagree; 5 = strongly agree). The weighted mean value is calculated and is used as a mean. The results are compiled in table 4 . From the responses of the workers, it appear that pain affect workers productivity (mean $=3.71$ ) and sleeping habit (mean $=3.5$ ) more than other items. Relationship with partner, friends and family is reported by workers as the third highly affected item from pain with a mean score of 3.28. 


\begin{tabular}{|l|l|l|l|l|l|l|}
\hline \multirow{2}{*}{ Description } & 1 & 2 & 3 & 4 & 5 & \multirow{2}{*}{ Mean } \\
\cline { 2 - 7 } & $\begin{array}{l}\text { Strongly } \\
\text { Disagree }\end{array}$ & Disagree & $\begin{array}{c}\text { Neither } \\
\text { Agree } \\
\text { Nor } \\
\text { Disagree }\end{array}$ & Agree & $\begin{array}{c}\text { Strongly } \\
\text { Agree }\end{array}$ & \\
\hline $\begin{array}{l}\text { Mood } \\
\text { Walking } \\
\text { Ability }\end{array}$ & $3 \times 1=3$ & $1 \times 2=2$ & $2 \times 2=4$ & $4 \times 4=8$ & $4 \times 5=20$ & 2.64 \\
\hline $\begin{array}{l}\text { Work } \\
\text { Productivity }\end{array}$ & $2 \times 1=2$ & $1 \times 2=2$ & $3 \times 3=9$ & $5 \times 4=20$ & $3 \times 5=15$ & 3.71 \\
\hline $\begin{array}{l}\text { Relationship } \\
\text { with } \\
\text { Partner, } \\
\begin{array}{l}\text { Friends and } \\
\text { Family }\end{array}\end{array}$ & $2 \times 1=2$ & $2 \times 2=4$ & $4 \times 3=12$ & $3 \times 4=12$ & $3 \times 5=15$ & 3.28 \\
\hline $\begin{array}{l}\text { Sleep } \\
\text { Hobbies }\end{array}$ & $1 \times 1=1$ & $3 \times 2=6$ & $2 \times 2=4$ & $4 \times 4=8$ & $4 \times 5=20$ & 2.78 \\
\hline
\end{tabular}

\section{Table 4: Impacts of Pain on Workers Abilities}

Different studies have shown that musculoskeletal pain is common in construction workers worldwide. For instance, Boschman et al., (2012) concluded that in the Netherlands, two thirds of the 750 brick workers go through musculoskeletal pain. Similarly, Deros et al., (2014) in their research related to musculoskeletal pain in the Malaysian construction industry noted that more than $60 \%$ of construction workers in Malaysia suffered from body pain. Another musculoskeletal symptom survey among 200 cement and concrete workers conducted by Goldsheyder et al., (2004) reported that that $77 \%$ of the respondents experienced at least one musculoskeletal disorder in the last twelve months. A study conducted by Holmström (1992) on 1773 construction workers, in Sweden reported that approximately $92 \%$ of these workers experienced musculoskeletal symptoms. In this study, $46.66 \%$ of the workers reported to have musculoskeletal pain in the five main common body area, including neck, shoulder, lower back, leg and Knees. Many researchers have found that low back pain is very 
common among construction workers, especially those are working in concrete and structural iron work or working on floor and roof (Goldsheyder et al., (2004); Forde et al., (2005); Holmström and Engholm, 2003). Goldsheyder et al., (2004) further noted that neck pain is to be more common among the painters, insulators, and crane operators. Kuorinka (1997) considered the main causes of work related musculoskeletal symptoms to the repeating hand-operated tasks such as transporting, lifting, or moving heavy materials or equipment and longer duration of a static uncomfortable position. Thus, it is necessary to develop effective intervention strategies to eliminate or reduce the risk of work related musculoskeletal symptoms. One of the best control measures is to involve and implement the participatory ergonomics. Kuorinka (1997) defined participatory ergonomics as increasing the participation of those who are doing a specific work activity using a problem solving approach for reducing the factors associated with the risk. The National Research Council has recognized the participatory ergonomics as an important and useful strategic tool to reduce the workers musculoskeletal pain, psychosocial risk, and increase productivity (NRC, 2001). Vi, (2003) suggested the adoption of an automatic apparatus to reduce uncomfortable positions and physical exertion. In this study, the author explained the ergonomic and biomechanical advantages of using the rebar-tying machine, which can reduce more than $50 \%$ of the peak low back loading. Many researchers regarded work safety climate as a significant element to the improved occupational health and safety of construction workers (Umar and Wamuziri, 2016-c; Umar and Wamuziri, 2016-d; Umar et al. (2017). Arcury et al., (2012) concluded that workers who anticipated a less safe climate were at a high exposure of having musculoskeletal pain. It was concluded in the investigation conducted by Fung et al., (2008) that construction workers normally do not understand that how much musculoskeletal injuries are serious which can have a high social impact on their life. Thus it is necessary to promote the awareness on musculoskeletal pain and injuries among construction workers. Strategies need to be developed to provided education and training to construction organizations on how to protect their workers from musculoskeletal pain and injuries.

\section{Conclusion:}

Worldwide construction is known as one of the main hazardous industries wherein health and safety in construction is considered an important element internationally. There have been many efforts in reducing safety risk; however, less thought is given to occupational health issues. In this article, the result of a study related to health factors of construction workers in Oman is presented. Data from 30 construction workers with different background and occupation, working on a major highway project in Oman was collected and analyzed. From the BMI calculation, it was found that $46.7 \%$ of the participants were over weighted while $27 \%$ of the participants were classified as obese. 
The assessment of measured blood pressure reveals that the blood pressure of $43.3 \%$ of the participants was more than the threshold and the fall under the hypertension values. Due to the climatic condition of the Middle East region, hypertension construction workers are expected to be effected more by heat stress. RHR of $6.66 \%$ of the participants were lower and for one of the participant it was higher than the normal; however it seems to be usual thus was not considered as significant. $46.60 \%$ of the workers reported that they experienced musculoskeletal pain in the past three months. Common areas of the body reported by workers for musculoskeletal pain include neck, shoulder, lower back, leg and knees. The workers who reported to have musculoskeletal pain were 35 years or above. The participants who have seven or more than seven hours daily sleep, reported low average pain compared to those who have less than seven hours daily sleep. A majority $(57 \%)$ of the workers use pain killer for the relief of pain while $22 \%$ of the workers reported that they just ignore the pain. The musculoskeletal pain was considered to have an impact on the daily life of the workers in which work productivity was on the top follow by sleep habit and family relationship. There is a need for a collaborative effort from all stakeholders which may include occupational health trainings and educational for the improvement of the health status of construction workers. Awareness on adopting healthy lifestyle, following best occupational health work practices and using ergonomic principles and personal protection would be beneficial. Construction organizations in GCC particularly can play a significant role to promote a safety culture. The use of safety climate concept for improved safety and health performance need to be adopted. Allowing workers for regular break to avoid a stationary work status and the effective implementation daytime break in summer would further improve the health condition of construction workers. Moreover, similar studies need to be conducted on a consistence basis to oversee the health profile of construction workers. Further clinical examinations and assessment of other health related factors such as blood glucose, liver function, urea, cholesterol and uric acid would be useful.

\section{References:}

AHA, 2018. (American Heart Association). All About Heart Rate (Pulse), 2018. American Heart Association, Dallas, USA. See: http://www.heart.org/HEARTORG/Conditions/HighBloodPressure/GettheFactsAb outHighBloodPressure/All-About-Heart-RatePulse_UCM_438850_Article.jsp\#.Wpvjfx1ubIV (accessed: 04/03/2018).

Arcury, T.A., O'Hara, H., Grzywacz, J.G., Isom, S., Chen, H. and Quandt, S.A., 2012. Work safety climate, musculoskeletal discomfort, working while injured, and depression among migrant farmworkers in North Carolina. American journal of public health, 102(S2), pp.S272-S278. 
Assaf, S.A. and Al-Hejji, S., 2006. Causes of delay in large construction projects. International journal of project management, 24(4), pp.349-357.

Ayas, N.T., White, D.P., Manson, J.E., Stampfer, M.J., Speizer, F.E., Malhotra, A. and Hu, F.B., 2003. A prospective study of sleep duration and coronary heart disease in women. Archives of internal medicine, 163(2), pp.205-209.

Beevers, D.G.; MacGregor, G.A. Hypertension in Practice, 3rd ed.; CRC Press: Boca Raton, FL, USA, 1999.

Boschman, J.S., van der Molen, H.F., Sluiter, J.K. and Frings-Dresen, M.H., 2012. Musculoskeletal disorders among construction workers: a one-year follow-up study. BMC musculoskeletal disorders, 13(1), p.196.

Carey, R.M. and Whelton, P.K., 2018. Prevention, detection, evaluation, and management of high blood pressure in adults: synopsis of the 2017 American College of Cardiology/American Heart Association hypertension guideline. Annals of internal medicine. American College of Physicians, Pennsylvania, USA.

Chan, D.W. and Kumaraswamy, M.M., 1997. A comparative study of causes of time overruns in Hong Kong construction projects. International Journal of project management, 15(1), pp.55-63.

Claessen, H., Arndt, V., Drath, C. and Brenner, H., 2009. Overweight, obesity and risk of work disability: a cohort study of construction workers in Germany. Occupational and environmental medicine, 66(6), pp.402-409.

Daskalopoulou, S.S., Rabi, D.M., Zarnke, K.B., Dasgupta, K., Nerenberg, K., Cloutier, L., Gelfer, M., Lamarre-Cliche, M., Milot, A., Bolli, P. and McKay, D.W., 2015. The 2015 Canadian Hypertension Education Program recommendations for blood pressure measurement, diagnosis, assessment of risk, prevention, and treatment of hypertension. Canadian Journal of Cardiology, 31(5), pp.549-568.

Deros, B.M., Daruis, D.D., Khamis, N.K., Mohamad, D., Daud, S.F.M., Amdan, S.M., Aziz, R.A. and Jamal, N., 2014. Prevalence of work related musculoskeletal disorders symptoms among construction workers: a case study in Malaysia. Iranian Journal of Public Health, 43(3), p.53.

Di Milia, L. and Mummery, K., 2009. The association between job related factors, short sleep and obesity. Industrial Health, 47(4), pp.363-368.

Dua, S., Bhuker, M., Sharma, P., Dhall, M. and Kapoor, S., 2014. Body mass index relates to blood pressure among adults. North American journal of medical sciences, 6(2), p.89.

Forde, M.S., Punnett, L. and Wegman, D.H., 2005. Prevalence of musculoskeletal disorders in union ironworkers. Journal of occupational and environmental hygiene, 2(4), pp.203-212.

Fung, I.W.H., Tam, V.W.Y., Tam, C.M. and Wang, K., 2008. Frequency and continuity of work-related musculoskeletal symptoms for construction workers. Journal of Civil Engineering and Management, 14(3), pp.183-187. 
Gangwisch, J.E., Heymsfield, S.B., Boden-Albala, B., Buijs, R.M., Kreier, F., Pickering, T.G., Rundle, A.G., Zammit, G.K. and Malaspina, D., 2006. Short sleep duration as a risk factor for hypertension: analyses of the first National Health and Nutrition Examination Survey. hypertension, 47(5), pp.833-839.

GLMN (Gulf Labour Markets and Migration), 2017. Demography, Migration, and the Labour Market in Qatar. GLMM - EN - No. 3/2017. Migration Policy Centre Robert Schuman Centre for Advanced Studies European University Institute, Florence, Italy. See: http://gulfmigration.eu/media/pubs/exno/GLMM_EN_2017_03.pdf (accessed 29/04/2018).

Goldsheyder, D., Weiner, S.S., Nordin, M. and Hiebert, R., 2004. Musculoskeletal symptom survey among cement and concrete workers. Work, 23(2), pp.111-121.

Gottlieb, D.J., Punjabi, N.M., Newman, A.B., Resnick, H.E., Redline, S., Baldwin, C.M. and Nieto, F.J., 2005. Association of sleep time with diabetes mellitus and impaired glucose tolerance. Archives of internal medicine, 165(8), pp.863-867.

Groeneveld, I.F., Proper, K.I., van der Beek, A.J., van Duivenbooden, C. and van Mechelen, W., 2008. Design of a RCT evaluating the (cost-) effectiveness of a lifestyle intervention for male construction workers at risk for cardiovascular disease: the health under construction study. BMC Public Health, 8(1), p.1.

Gupta, N., Heiden, M., Mathiassen, S.E. and Holtermann, A., 2018. Is self-reported time spent sedentary and in physical activity differentially biased by age, gender, body mass index, and low-back pain?. Scandinavian journal of work, environment \& health, 44(2), pp.163-170.

Holmström, E. and Engholm, G., 2003. Musculoskeletal disorders in relation to age and occupation in Swedish construction workers. American journal of industrial medicine, 44(4), pp.377-384.

Holmström, E.B., 1992. Musculoskeletal disorders in construction workers related to physical, psychosocial, and individual factors. Acta Orthopaedica Scandinavica, 63(sup247), pp.55-55.

ILO, 2015. (International Labour Organization). Construction: a hazardous work. See: http://www.ilo.org/safework/areasofwork/hazardous-work/WCMS_356576/lang-en/index.htm (accessed 11/03/2017).

Kaming, P.F., Olomolaiye, P.O., Holt, G.D. and Harris, F.C., 1997. Factors influencing construction time and cost overruns on high-rise projects in Indonesia. Construction Management \& Economics, 15(1), pp.83-94.

Kawai, N., Kawai, T. and Kawai, K., 1995. Ultrasonic and laboratory studies on fatty liver in white-collar workers. Nihon Shokakibyo Gakkai zasshi= The Japanese journal of gastro-enterology, 92(7), pp.1058-1065.

Kuorinka, I., 1997. Tools and means of implementing participatory ergonomics. International Journal of Industrial Ergonomics, 19(4), pp.267-270. 
Lombardi, D.A., Folkard, S., Willetts, J.L. and Smith, G.S., 2010. Daily sleep, weekly working hours, and risk of work-related injury: US National Health Interview Survey (2004-2008). Chronobiology international, 27(5), pp.1013-1030.

Marshall, N.S., Glozier, N. and Grunstein, R.R., 2008. Is sleep duration related to obesity? A critical review of the epidemiological evidence. Sleep medicine reviews, 12(4), pp.289-298.

NAO (National Audit Office), 2003. Construction Performance. National Audit Office, Victoria, London, UK. See: https://www.nao.org.uk/report/pfi-constructionperformance/ (accessed 25/04/2018).

NCSI (2015) National Centre for Statistics and Information, Oman Statistical Year Book Issued No. 43. See:

https://www.ncsi.gov.om/Elibrary/LibraryContentDoc/ben_Statistical_Year_Book_ 2015_740d0da1-01d2-4f42-a159-6102a49ecf59.pdf (accessed 03/03/2018).

NCSI, 2017. National Centre for Statistics and Information. Monthly Statistical Bulletin, January, 2017. National Centre for Statistics and Information, Muscat, Oman.

Nicholas, J.M. and Steyn, H., 2017. Project management for engineering, business and technology. Taylor \& Francis, Abingdon, United Kingdom.

NRC, 2001. (National Research Council), 2001. Musculoskeletal disorders and the workplace: low back and upper extremities. National Academies Press. Washington, DC, USA, 2001; pp. 301-329.

ONS, 2017. (Office for National Statistics). Construction statistics: Number 18, 2017 edition. Office for National Statistics, 2017. UK. See:

https://www.ons.gov.uk/businessindustryandtrade/constructionindustry/articles/co nstructionstatistics/number182017edition (accessed 01/02/2018).

PASI, 2012. (Public Authority for Social Insurance). 19th Annual Report 2012. Public Authority for Social Insurance, Muscat, Oman. See:

https://www.pasi.gov.om/en/Pages/AboutUs/AnnualReports.aspx (accessed 12/02/2018).

PASI, 2013. (Public Authority for Social Insurance). 20th Annual Report 2013. Public Authority for Social Insurance, Muscat, Oman. See:

https://www.pasi.gov.om/en/Pages/AboutUs/AnnualReports.aspx (accessed 12/02/2018).

PASI, 2014. (Public Authority for Social Insurance). 21th Annual Report 2013. Public Authority for Social Insurance, Muscat, Oman. See:

https://www.pasi.gov.om/en/Pages/AboutUs/AnnualReports.aspx (accessed 12/02/2018).

PASI, 2015. (Public Authority for Social Insurance). 22nd Annual Report 2013. Public Authority for Social Insurance, Muscat, Oman. See: https://www.pasi.gov.om/en/Pages/AboutUs/AnnualReports.aspx (accessed 12/02/2018). 
PASI, 2016. (Public Authority for Social Insurance). 23rd Annual Report 2013. Public Authority for Social Insurance, Muscat, Oman. See:

https://www.pasi.gov.om/en/Pages/AboutUs/AnnualReports.aspx (accessed 12/02/2018).

Poulter, N.R.; Prabhakaran, D.; Causlfield, M. 2015. Hypertension. Lancet, 386 (995): 801-812.

Rees, K., Dyakova, M., Ward, K., Thorogood, M. and Brunner, E., 2013. Dietary advice for reducing cardiovascular risk. Cochrane Database Syst Rev, 3.

Sambasivan, M. and Soon, Y.W., 2007. Causes and effects of delays in Malaysian construction industry. International Journal of project management, 25(5), pp.517-526.

SCA (Saudi Contractors Authority) 2017. Saudization in Construction. Saudi Contractors Authority, Riyadah, Saudi Arabia.

SHJ, 2017. (Statistical Handbook of Japan). Manufacturing and Construction. Statistical Handbook of Japan, 2017. Statistics Bureau, Ministry of Internal Affairs and Communication, Tokyo, Japan. See: http://www.stat.go.jp/english/data/handbook/pdf/2017all.pdf (accessed 01/02/2018).

Singh, M., Drake, C.L., Roehrs, T., Hudgel, D.W. and Roth, T., 2005. The association between obesity and short sleep duration: a population-based study. Journal of clinical sleep medicine, 1(04), pp.357-363.

Statista, 2016. Number of employed persons in the United Arab Emirates in 2016, by economic sector. Statista, Hamburg, Germany. See: https://www.statista.com/statistics/638515/uae-total-number-of-workforce-byeconomic-sector/ (accessed 22/04/2018).

Statista, 2017. Construction industry spending worldwide from 2014 to 2025 (in trillion U.S. dollars). Statista, Inc. New York, USA. See: https://www.statista.com/statistics/788128/construction-spending-worldwide/ (accessed 24/04/2018).

Tse, M.; Wan, V.T.; Wong, A.M. Pain and pain-related situations surrounding community-dwelling older persons. J. Clin. Nurs. 2013, 22, 1870-1879.

Tse, M.M.Y.;Wan, V.T.C.; Ho, S.S.K. Profile of pain and use of pharmacological and non-pharmacological methods for relieving pain in older persons in nursing homes. J. Pain Manag. 2010, 3, 309-317.

Umar, T. and Egbu, C. (2018-a), June. Global Commitment Towards Sustainable Energy. In Proceedings of the Institution of Civil Engineers-Engineering Sustainability (pp. 1-38). Thomas Telford Ltd. https://doi.org/10.1680/jensu.17.00059.

Umar, T. and Egbu, C. (2018-b). Perceptions on Safety Climate: A Case Study in the Omani Construction Industry. Proceedings of the Institution of Civil EngineersManagement, Procurement and Law. DOI: 10.1680/jmapl.18.00001. 
Umar, T. and Egbu, C. (2018-d). Heat Stress, a Hidden Cause of Accidents in Construction. Proceedings of the Institution of Civil Engineers- Municipal Engineer. DOI: $10.1680 /$ jmuen.18-00004.

Umar, T. and Wamuziri, S., 2016-a. Briefing: Conventional, wind and solar energy resources in Oman. Proceedings of the Institution of Civil Engineers-Energy, 169(4), pp.143-147.

Umar, T. and Wamuziri, S., 2016-c, June. Briefing: Using 'safety climate factors' to improve construction safety. In Proceedings of the Institution of Civil EngineersMunicipal Engineer (Vol. 170, No. 2, pp. 65-67). Thomas Telford Ltd.

Umar, T. and Wamuziri, S.C., 2016-b. "A Review of Construction Safety, Challenges and Opportunities - Oman Perspective". In Y G Sandanayake, G I Karunasena, and T Ramachandra (Editors). Proceedings of 5th World Construction Symposium 2016, 29-31 July 2016, University of Moratuwa, Colombo, Sri Lanka. Pages 14-22, ISSN 2362-0919. http://dl.lib.mrt.ac.lk/handle/123/11910.

Umar, T. and Wamuziri, S.C., 2016-d. "Using Safety Climate As A Tool For Improvement Of Safety Performance In Construction Organizations". In Y G Sandanayake, G I Karunasena, and T Ramachandra (Editors). Proceedings of 5th World Construction Symposium 2016, 29-31 July 2016, University of Moratuwa, Colombo, Sri Lanka. Pages 14-22, ISSN 2362-0919. http://dl.lib.mrt.ac.Ik/handle/123/11910.

Umar, T., 2016-a, December. Briefing: Cost of accidents in the construction industry of Oman. In Proceedings of the Institution of Civil Engineers-Municipal Engineer (Vol. 170, No. 2, pp. 68-73). Thomas Telford Ltd. https://doi.org/10.1680/jmuen.16.00032.

Umar, T., 2016-b, May. Briefing: Defining safety leadership in construction. In Proceedings of the Institution of Civil Engineers-Municipal Engineer (Vol. 170, No. 1, pp. 3-5). Thomas Telford Ltd. https://doi.org/10.1680/jmuen.16.00004.

Umar, T., 2017-a. Geothermal energy resources in Oman. Proceedings of the Institution of Civil Engineers-Energy. DOI: 10.1680/jener.17.00001.

Umar, T., 2017-b. Towards a sustainable energy: the potential of biomass for electricity generation in Oman. Proceedings of the Institution of Civil Engineers-Engieering Sustainability. DOI: 10.1680/jensu.17.00001.

Umar, T., 2018. Causes of delay in construction projects in Oman. Middle East Journal of Management, 5(2), pp.121-136.

Umar, T., Egbu, C., Wamuzir, S. and Honnurvali, M.S., 2018. Occupational Safety and Health Regulations in Oman. Proceedings of the Institution of Civil Engineers: Management, Procurement and Law. DOI: 10.1680/jmuen.16.00032.

Umar, T., Wamuziri, S. and Egbu, C. "Causes Of Accidents In Highway Construction Projects In Oman". In Y G Sandanayake, T. Ramachandra and S. Gunatilake (Editors). Proceedings of the 6th World Construction Symposium 2017, 30th June - 02nd July 2017. University of Moratuwa, Colombo, Sri Lanka. Pages 96 105. ISSN: 2362-0919. 
Umar, T., Wamuziri, S. and Egbu, C. "Factors that Influence Safety Climate in Construction in Oman". In Fidelis Emuze and Mike Behm (Editors). Proceedings of Joint CIB W099 and TG59 International Safety, Health, and People in Construction Conference. 2017. 11-13 June 2017, Cape Town, South Africa. Pages 99 - 113, ISBN: 978-1-920508-78-4.

Ventures, 2018-a. US\$29.4 Bn worth of contracts awarded in GCC in Q1, 2018. Ventures Middle East DMCC Venture Onsite. Dubai, UAE. See: https://www.venturesonsite.com/search/projects?q=US\%24+29.4+Bn.+worth+of+ contracts+awarded+in+GCC (accessed 29/04/2018).

Ventures, 2018-b. KSA Construction Market Overview. Ventures Middle East DMCC Venture Onsite. Dubai, UAE. See: https://www.venturesonsite.com/constructionreport/196-ksa-construction-market-overview---march (accessed 29/04/2018).

Vi, P., 2003. Reducing risk of musculoskeletal disorders through the use of rebar-tying machines. Applied occupational and environmental hygiene, 18(9), pp.649-654.

Viester, L., Verhagen, E.A., Bongers, P.M. and van der Beek, A.J., 2018. Effectiveness of a Worksite Intervention for Male Construction Workers on Dietary and Physical Activity Behaviors, Body Mass Index, and Health Outcomes: Results of a Randomized Controlled Trial. American Journal of Health Promotion, 32(3), pp.795-805.

Westerlund, H., Alexanderson, K., Åkerstedt, T., Hanson, L.M., Theorell, T. and Kivimäki, M., 2008. Work-related sleep disturbances and sickness absence in the Swedish working population, 1993-1999. Sleep, 31(8), pp.1169-1177.

WHO (2017). (World Health Organization). Health Equity Assessment Toolkit (HEAT). Version 2.0. Geneva, World Health Organization, 2017. See: http://www.who.int/gho/health_equity/heat_technical_notes.pdf?ua=1 (accessed 15/01/2017).

Yi, W. and Chan, A., 2016. Health Profile of Construction Workers in Hong Kong. International journal of environmental research and public health, 13(12), p.1232.

Yi, W., and Chan, Albert, P.C. (2017). Effects of Heat Stress on Construction Labor Productivity in Hong Kong: A Case Study of Rebar Workers. International Journal of Environmental Research and Public Health. DOI: 10.3390/ijerph14091055.

Punnett, L. and Wegman, D.H., 2004. Work-related musculoskeletal disorders: the epidemiologic evidence and the debate. Journal of electromyography and kinesiology, 14(1), pp.13-23. https://doi.org/10.1016/j.jelekin.2003.09.015.

Leung, M.Y., Chan, I.Y.S. and Yu, J., 2012. Preventing construction worker injury incidents through the management of personal stress and organizational stressors. Accident Analysis \& Prevention, 48, pp.156-166. https://doi.org/10.1016/j.aap.2011.03.017. 
ACSA (Alberta Construction Safety Association), 2008. Lost-Time Claims, Disabling Injury Claims and Claim Rates-2003 to 2007. Alberta Construction Safety Association, Alberta, Canada. See:

http://www.assembly.ab.ca/lao/library/egovdocs/2007/aleii/163440_07.pdf (accessed 18/09/2018). 